\title{
JURNAL SOLUSI
}

\section{Penanggung Jawab}

Alief Indita Agustyani, SE., MM

\section{Redaktur Pelaksana}

Drs. Junaidi Affan, MM

\section{Dewan Penyunting}

Dr. Zainal Mustafa EQ (Universitas Islam Indonesia Yogyakarta)

Drs. H IrfanNursasmita, M.Si,.Ak (Universitas Gadjah Mada)

Dr. H Bachruddin, M.Si (Universitas Islam Indonesia Yogyakarta)

Dr. Dwi Praptono Agus Harjito (Universitas Islam Indonesia Yogyakarta)

Drs. Kadari, M.M.,M.Si., Ak. (Sekolah Tinggi Ilmu Ekonomi YKP Yogyakarta)

\section{Sekretaris}

Surya Widya

Mukaromah

\author{
Alamat Sekretariat \\ STIE SBI Yogyakarta \\ Jl.Ring Road Utara No.17 Condong Catur Yogyakarta \\ Phone 0274-887984 \\ Email: lppmstiesbi@gmail.com
}

\section{Distribusi dan Sirkulasi}

Bag. Perpustakaan STIE SBI Yogyakarta 


\section{DAFTAR ISI}

Krisna Mutiara Wati

Muhammad Robi' Nurwahyudi

Hardoko

Teguh Budi Prasetya, Niken Widyastuti

Yunita Fitri Wahyuningtyas, Fatmawati

Tyas Zakiya Prakasa, Eliya Isfaatun
Faktor-Faktor yang Mempengaruhi Minat Berwirausaha Mahasiswa (Studi pada Mahasiswa Fakultas Ekonomi dan Sosial Universitas Jenderal Achmad Yani Yogyakarta) $\sim 1$

Pengaruh Tingkat Pendidikan terhadap Tingkat Kesejahteraan Masyarakat di Kabupaten Bantul 17

Pengaruh e-WOM (Electronic Word of Mouth) Terhadap Keputusan Pembelian online di Daerah Istimewa Yogyakarta 33

Penguatan Kelembagaan Sosial-Ekonomi Desa Melalui BUMDes Panggung Lestari di Desa Panggungharjo, Kecamatan Sewon Kabupaten Bantul 55

Pengaruh Produk, Harga, Tempat dan Promosi (Marketing Mix) Terhadap Keputusan Pembelian Konsumen di Dapur Mpok Duren 63

Perkembangan Perpajakan di Indonesia $\sim 79$

Rizki Ramadhan, Pengaruh Kesadaran Wajib Pajak, Pelayanan Fiskus, Enita Binawati dan Sanksi Administrasi Terhadap Kepatuhan Wajib Pajak dalam Membayar Pajak Kendaraan Bermotor Menggunakan Metode Mix Method (Pada Kantor Pelayanan Pajak Kendaraan Bermotor Samsat Kota Yogyakarta) $\sim 95$ 


\title{
Pengaruh Kesadaran Wajib Pajak, Pelayanan Fiskus, dan Sanksi Administrasi Terhadap Kepatuhan Wajib Pajak dalam Membayar Pajak Kendaraan Bermotor Menggunakan Metode Mix Method (Pada Kantor Pelayanan Pajak Kendaraan Bermotor Samsat Kota Yogyakarta)
}

\author{
${ }^{1}$ Rizki Ramadhan, ${ }^{2}$ Enita Binawati \\ ${ }^{1}$ ramadhanrizki1133@gmail.com, ${ }^{2}$ enitabinawati@gmail.com \\ Jurusan Akuntansi, Sekolah Tinggi Ilmu Ekonomi SBI Yogyakarta
}

\begin{abstract}
Tax is the main source of state revenues where the activity of countries such as national development funded by tax. National development funded is difficult to do if there is no revenue from tax sector. To make the effectiveness of development equity, decentralization from the central government to supervise and arrange directly about affairs in the regions is needed that policy, planning, implementation, and financing are given to the regional government. The purpose of this research is to find the influence of the awareness of taxpayers, the quality of services, and the tax penalty toward taxpayers compliance. The method used in this research is explanatory research. Accidental sampling technique is used by spreading questionnaires to one hundred taxpayers vehicles registered in samsat tax office of Yogyakarta. Besides spreading the questionares writer did an interview to the responden so that in this research writer use mix method. The research result indicates that awareness taxpayers have a positif impact toward the compliance of taxpayers' motor vehicles registered in samsat tax office of Yogyakarta and quality of services, and tax penalties have a negatif impact toward the compliance of taxpayers' motor vehicles registered in samsat tax office of Yogyakarta.
\end{abstract}

Keywords: taxpayers, tax revenue, local taxes, vehicles, compliance

\section{PENDAHULUAN}

Pajak merupakan penerimaan terbesar sama suatu negara khususnya negara Indonesia. Pendapatan negara pada tahun 2017 sebesar 85,64\% (1,5 kuadriliun) berasal dari pajak, $14,28 \%$ (250 triliun) penerimaan bukan pajak dan sebesar $0,1 \%$ (1,4 triliun) dari hibah (TribunNews, 2017). Dominasi pajak sebagai sumber penerimaan merupakan satu hal yang sangat wajar, ketika sumber daya alam, khususnya minyak bumi tidak bisa lagi diandalkan. Penerimaan dari suatu sumber daya alam mempunyai umur relatif terbatas yang suatu saat akan habis dan tidak bisa diperbaharui lagi. Hal ini berbeda dengan pajak, sumber penerimaan ini mempunyai umur tidak terbatas, apalagi seiring 
dengan bertambahnya jumlah penduduk, maka akan semakin besar pula penerimaan negara dari sektor pajak.

Pembayaran pajak merupakan perwujudan dari kewajiban negara dan peran serta masyarakat mengumpulkan dana untuk membiayai negara dan pembangunan nasional. Pajak yang bertujuan meningkatkan kesejahteraan seluruh rakyat melalui perbaikan dan penambahan pelayanan publik, mengalokasikan pajak tidak hanya untuk rakyat pembayar pajak juga untuk kepentingan rakyat yang tidak wajib membayar pajak.

Kemauan wajib pajak membayar pajak merupakan hal penting dalam pemungutan pajak. Penyebab kurangnya kemauan membayar pajak tersebut adalah karenan azas perpajakan, yaitu karna hasil pemungutan pajak tidak langsung dinikmati oleh wajib pajak. Harus disadari bahwa jalan-jalan yang halus, pusat-pusat kesehatan masyarakat, pembangunan sekolah-sekolah negeri, irigasi yang baik, dan fasilitas-fasilitas publik lainnya yang dapat dinikmati oleh masyarakat merupakan hasil dari pembayaran pajak. Namun pada kenyataannya masyarakat tidak mau membayar pajak. Hal ini disebabkan masyarakat tidak pernah tahu wujud konkret imbalan dari uang yang dikeluarkan untuk membayar pajak.

Widayati dan Nurlis (2010) menyatakan bahwa kemauan membayar pajak dipengaruhi oleh beberapa faktor, yaitu kesadaran dalam membayar pajak, pemahaman dan pengetahuan tentang peraturan perpajakan, persepsi yang baik terhadap efektifitas sistem perpajakan. Berdasarkan uji parsial, faktor kesadaran membayar pajak dan persepsi atas efektifitas sistem perpajakan mempunyai pengaruh yang tidak signifikan terhadap kemauan wajib pajak untuk membayar pajak. Sedangkan faktor pengetahuan dan pemahaman tentang peraturan pajak dan kualitas pelayanan mempunyai pengaruh yang signifikan terhadap kemauan wajib pajak untuk membayar pajak. Pemungutan pajak memang bukan suatu pekerjaan yang mudah, disamping peran serta aktif dari petugas perpajakan, juga dituntut kemauan dari para wajib pajak itu sendiri.

Perpajakan di Indonesia menganut sistem self assessment yang memberi kepercayaan terhadap wajib pajak untuk menghitung, menyetor dan melapor sendiri pajaknya, menyebabkan kebenaran pembayaran pajak tergantung pada kejujuran wajib pajak sendiri dalampelaporan kewajiban perpajakannya. Sistem pemungutan pajak di Indonesia berubah dari official assessment system menjadi seft assessment system. Official assessment system merupakan sistem pemungutan pajak yang memberi wewenang kepada fikus untuk menentukan besarnya pajak terutang oleh wajib pajak. Seft assessment system merupakan sistem pemungutan pajak yang memberi wewenang kepada wajib pajak untuk menentukan besarnya pajak terutang.

Seft assessment system menuntut adanya peran aktif masyarakat dalam melaksanakan kewajiban perpajakan. Kesadaran dan kepatuhan yang tinggi dari wajib pajak merupakan faktor terpenting dari sistem pelaksanaan sistem tersebut. Salah satu upaya dalam meningkatkan kepatuhan wajib pajak dalam memberikan pelayanan yang baik kualitas dan kuantitas pelayanan diharapkan dapat meningkatkan kepuasan kepada wajib pajak sebagai pelanggan, maka dapat meningkatkan kepatuhan dalam 
bidang perpajakan. Paradigma baru yang menetapkan aparat pemerintah sebagai abdi negara di masyarakat (wajib pajak) harus diutamakan agar dapat meningkatkan kinerja pelayanan publik. Undang-undang tentang perpajakan dengan jelas mencantumkan kewajiban para wajib pajak membayar pajak, jika tidak memenuhi kewajiban tersebut maka sanksi yang dikenakan jelas.

Akan sangat relevan apabila menempatkan kesadaran dalam membayar pajak dari para wajib pajak bukan hanya sekedar sebagai wacana tetapi lebih dari itu, kita seharusnya juga memandang dalam membayar pajak sebagai objek sorotan secara efektif bahkan mendekati kebenaran dalam mensukseskan program yang dicanangkan Direktorat Jendral Pajak tersebut. Perlakuan tersebut bukan berarti akan menempatkan wajib pajak di pihak yang lebih baik, tetapi harus diakui secara jujur, masih kurangnya kesadaran masyarakat terhadap pajak dikarenakan masih sangat minimnya pengetahuan masyarakat mengenai perpajakan.

Selain pelayanan yang dilakukan dengan baik diperlukan juga adanya sanksi yang menjadi kontrol bagi wajib pajak, sanksi perpajakan yang akan diterima wajib pajak adalah faktor lain yang dapat mempengaruhi peningkatan kepatuhan wajib pajak kendaraan bermotor. Menurut Muliari dan Setiawan (2009:2) banyak faktor yang dapat mempengaruhi kepatuhan wajib pajak selain pelayanan fiskus yang baik, penegakan hukum perpajakan juga akan mempengaruhi kepatuhan wajib pajak. Terdapat undangundang yang mengatur tentang ketentuan dan tata cara perpajakan, agar ketentuan pajak dipatuhi maka harus ada sanksi perpajakan bagi para pelanggarnya.

Dalam rangka pemerataan pelaksaan pembangunan, pemerintah pusat tidak mungkin dapat melaksanakannya secara efektif. Desentralisasi dari pemerintah pusat untuk mengawasi serta mengatur secara langsung urusan- urusan yang ada di daerah sangat dibutuhkan, demi efisiensi dan efektifivitas penyelenggaran urusan-urusan pemerintah pusat tersebut, maka sebagian urusan-urusan tersebut di serahkan kepada daerah, yaitu pemerintah daerah. Baik yang menyangkut kebijakan, perencanaan, pelaksanaan maupun pembiayaan namun tidak lepas daripada tanggung jawab pemerintah daerah kepada pemerintah pusat, sehingga daerah dapat memiliki pendapatan yang disebut Pendapatan Asli Daerah (PAD).

Jenis pajak terbagi menjadi dua yaitu pajak yang dipungut dan dikelola oleh pemerintah pusat yang disebut pajak pusat dan pajak yangdipungut serta dikelola oleh pemerintah tiap-tiap daerah yang disebut pajak daerah. Salah satu jenis pajak daerah yang merupakan sumber pendapatan daerah terbesar yaitu Pajak Kendaraan Bermotor. Pajak Kendaraan Bermotor atau yang biasa dikenal dengan PKB merupakan pajak terhadap kepemilikan ataupun penguasaan kendaraan bermotor baik kendaraan bermotor roda dua atau lebih dan beserta gandengannya yang dipergunakan pada seluruh jenis jalan darat serta digerakkan oleh peralatan teknik yang berupa motor atau peralatan yang lain yang berfungsi merubah sumber daya energi menjadi sebuah tenaga gerak pada kendaraan bermotor yang bersangkutan, termasuk alat alat besar yang bisa bergerak (UU No. 28 tahun 2009 tentang Pajak dan Retribusi Daerah). 
Peningkatan jumlah kendaraan bermotor saat ini berkembang sangat pesat dan seakan tidak dapat dikendalikan, menurut data Dinas Perhubungan Kota Yogyakarta jumlah kendaraan roda 2 tahun 2016 sejumlah 71.566 unit. Tahun 2017 meningkat 211 persen menjadi 222.915 unit. Sementara untuk kendaraan roda 4, tahun 2016 sejumlah 12.746 unit. Tahun 2017 meningkat 344 persen menjadi 56.647 unit. Dengan banyaknya kendaraan bermotor di Yogyakarta khususnya daerah kota, seharusnya pemerintah daerah bisa mendapatkan lebih penerimaan pajak dari sektor ini, tapi dilihat dari realisasinya pemerintah tidak bisa memaksimalkan pendapatan dari sektor ini karena beberapa kendala yaitu diantaranya kepatuhan dan kesadaran wajib pajak dalam membayar pajak kendaraan bermotornya.

\section{TINJAUAN PUSTAKA}

Waluyo dan Ilyas (2005:8) mendefinisikan pajak adalah iuran kepada negara (yang dapat dipaksakan) yang terutang oleh yang wajib membayarnya menurut peraturan-peraturan, dengan tidak mendapat prestasi kembali, yang langsung dapat ditunjuk, dan yang gunanya adalah untuk membiayai pengeluaran-pengeluaran umum sehubungan dengan tugas negara untuk menyelenggarakan pemerintahan.

Sementara menurut Soemitro (1990) pajak adalah iuran rakyat kepada kas negara berdasarkan undang-undang (yang dapat dipaksakan) dengan tiada mendapat jasa timbal (kontra prestasi) yang langsung dapat ditunjukkan dan yang digunakan untuk membayarpengeluaran umum.

\section{Pajak Daerah}

Marihot (2013:9) menyatakan bahwa pajak daerah adalah iuran wajib yang dilakukan oleh daerah kepada orang pribadi atau badan tanpa imbalan langsung yang seimbang, yang dapat dipaksakan berdasarkan peraturan perundang-undangan yang berlaku, yang digunakan untuk membiayai penyelenggaraan pemerintah daerah dan pembangunan daerah. Menurut UU Nomor 28 Tahun 2009, pajak daerah adalah kontribusi wajib kepada daerah yang terutang oleh orang pribadi atau badan yang bersifat memaksa berdasarkan undang-undang, dengan tidak mendapatkan imbalan secara langsung dan digunakan untuk keperluan daerah sebesar-besarnya kemakmuran rakyat. Pajak daerah terbagi menjadi dua bagian yaitu pajak provinsi dan pajak kabupaten/kota.

\section{Wajib Pajak}

Menurut Suandy (2002: 3), "wajib pajak adalah orang pribadi atau badan yang menurut ketentuan peraturan perundangundangan perpajakan ditentukan untuk melakukan kewajiban perpajakan, termasuk pemungut pajak atau pemotong pajak tertentu".

Menurut Ilyas, W dan Richard (2010 :201) mengatakan bahwa hak WP yang diatur dalam UU Perpajakan adalah: 
1. Hak untuk mendapatkan pembinaan dan pengarahan dari fiskus.

2. Hak untuk membetulkan Surat Pemberitahuan.

3. Hak untuk memperpanjang waktu penyampaian Surat Pemberitahuan.

4. Hak memperoleh kembali kelebihan pembayaran pajak.

5. Hak mengajukan keberatan.

Kepatuhan Pajak

Menurut Norman D. Nowak (Moh. Zain: 2004), Kepatuhan Wajib Pajak memiliki pengertian yaitu: Suatu iklim kepatuhan dan kesadaran pemenuhan kewajiban perpajakan, tercermin dalam beberapa situasi, diantaranya:

1. Wajib pajak paham atau berusaha untuk memahami semua ketentuan peraturan perundang-undangan perpajakan.

2. Mengisi formulir pajak dengan lengkap dan jelas

3. Menghitung jumlah pajak yang terutang dengan benar

4. Membayar pajak yang terutang tepat pada waktunya.

Kepatuhan wajib pajak merupakan pemenuhan kewajiban perpajakan yang dilakukan oleh pembayar pajak dalam rangka memberikan kontribusi bagi pembangunan dewasa ini yang diharapkan di dalam pemenuhannya diberikan secara sukarela. Kepatuhan wajib pajak menjadi aspek penting mengingat sistem perpajakan Indonesia menganut self asessment system di mana dalam prosesnya secara mutlak memberikan kepercayaan kepada wajib pajak untuk menghitung, membayar dan melapor kewajibannya.

\section{Pajak Kendaraan Bermotor}

Jenis pajak yang diterapkan di Negara Republik Indonesia adalah (i) Pajak Pusat; dan (ii) Pajak Daerah. Berdasarkan Pasal 1 angka 10 Undang-undang Nomor 28 Tahun 2009 Tentang Pajak Daerah dan Retribusi Daerah (UU No. 28 Tahun 2009), definisi Pajak Daerah adalah kontribusi wajib kepada daerah yang terutang oleh orang pribadi atau badan yang bersifat memaksa berdasarkan Undang-undang, dengan tidak mendapatkan imbalan secara langsung dan digunakan untuk keperluan daerah bagi sebesar-besarnya kemakmuran rakyat. Adapun Pajak Kendaraan Bermotor termasuk ke dalam jenis pajak provinsi yang merupakan bagian dari Pajak Daerah. Lebih lanjut,Pajak Kendaraan Bermotor sebagaimana yangdidefinisikan dalam Pasal 1 angka 12 dan 13 UU No. 28 Tahun 2009 adalah pajak atas kepemilikan dan/atau penguasaan kendaraan bermotor.

Kendaraan Bermotor Pajak Kendaraan Bermotor (PKB) adalah pajak atas kepemilikan atau penguasaan kendaraan bermotor, yaitu kendaraan beroda dua atau lebih beserta gandengannya yang digunakan di semua jenis jalan darat dan digerakkan oleh peralatan teknik berupa motor atau peralatan lainnya yang berfungsi untuk mengubah suatu sumber daya energi tertentu menjadi tenaga gerak kendaraan bermotor yang bersangkutan, termasuk alat-alat besar yang bergerak (Tungka \& Sabijono, 2015). 


\section{Kesadaran Wajib Pajak}

Kesadaran merupakan unsur dalam diri manusia untuk memahami realitas dan bagaimana mereka bertindak atau bersikap terhadap realitas. Jatmiko (2006) menjelaskan bahwa kesadaran adalah keadaan mengetahui atau mengerti. Irianto (2005) menguraikan beberapa bentuk kesadaran membayar pajak yang mendorong wajib pajak untuk membayar pajak.

Pertama, kesadaran bahwa pajak merupakan bentuk partisipasi dalam menunjang pembangunan negara. Dengan menyadari hal ini, wajib pajak mau membayar pajak karena merasa tidak dirugikan dari pemungutan pajak yang dilakukan. Kedua, kesadaran bahwa penundaan pembayaran pajak dan pengurangan beban pajak sangat merugikan negara. Wajib pajak mau membayar pajak karena memahami bahwa penundaan pembayaran pajak dan pengurangan beban pajak berdampak pada kurangnya sumber daya finansial yang dapat mengakibatkan terhambatnya pembangunan negara. Ketiga, kesadaran bahwa pajak ditetapkan dengan Undang-undang dan dapat dipaksakan. Wajib pajak akan membayar karena pembayaran pajak disadari memiliki landasan hukum yang kuat dan merupakan kewajiban mutlak setiap warga negara.

Kesadaran Wajib Pajak dalam membayar pajak merupakan perilaku Wajib Pajak berupa pandangan atau perasaan yang melibatkan pengetahuan, keyakinan dan penalaran disertai kecenderungan untuk bertindak sesuai stimulus yang yang diberikan oleh sistem dan ketentuan pajak tersebut (Fikriningrum, 2012). Sedangkan menurut Nasution (2003:62). Kesadaran wajib pajak merupakan sikap wajib pajak yangtelah memahami dan mau melaksanakan kewajibannya untuk membayar pajak dan telah melaporkan semua penghasilannya tanpa ada yang disembunyikan sesuai dengan ketentuan yang berlaku.

\section{Pelayanan Fiskus}

Pelayanan adalah cara melayani (membantu mengurus atau menyiapkan segala kebutuhan yang diperlukan seseorang). Sementara itu, fiskus merupakan petugas pajak. Jadi, pelayanan fiskus dapat diartikan sebagai cara petugas pajak dalam membantu, mengurus, atau menyiapkan segala keperluan yang dibutuhkan seseorang yang dalam hal ini adalah wajib pajak (Jatmiko, 2006).

Kegiatan yang dilakukan otoritas pajak dengan menyapa masyarakat agar menyampaikan SPT tepat waktu, termasuk penyuluhan secara kontinyu melalui berbagai media, serta pawai peduli NPWP di jalan, patut untuk dipuji. Dengan penyuluhan secara terus-menerus kepada masyarakat agar mengetahui, mengakui, menghargai, dan menaati ketentuan pajak, diharapkan tujuan penerimaan pajak bisa berhasil.

\section{Sanksi Administrasi Perpajakan}

Sanksi adalah suatu tindakan berupa hukuman yang diberikan kepada orang yang melanggar peraturan. Peraturan atau Undang-undang merupakan rambu-rambu bagi seseorang untuk melakukan sesuatu mengenai apa yang harus dilakukan dan 
apa yang seharusnya tidak dilakukan. Sanksi diperlukan agar peraturan atau Undangundang tidak dilanggar. Sanksi pajak merupakan jaminan bahwa ketentuan peraturan perundang-undangan perpajakan (norma perpajakan) akan dituruti/ditaati/dipatuhi, dengan kata lain sanksi perpajakan merupakan alat pencegah agar wajib pajak tidak melanggar norma perpajakan (Mardiasmo,2006).

Pandangan tentang sanksi perpajakan tersebut diukur dengan indikator (Yadnyana, 2009) sebagai berikut.

a. Sanksi pidana yang dikenakan bagi pelanggar aturan pajak cukup berat.

b. Sanksi adminstrasi yang dikenakan bagi pelanggar aturan pajak sangat ringan.

c. Pengenaan sanksi yang cukup berat merupakan salah satu sarana mendidik wajib pajak.

d. Sanksi pajak harus dikenakan kepada pelanggarnya tanpa toleransi.

e. Pengenaan sanksi atas pelanggaran pajak dapat dinegosiasikan.

\section{METODA PENELITIAN}

Jenis penelitian yang digunakan dalam penelitian ini adalah penelitian explanatoryresearch dengan pendekatan kuantitatif dan kualitatif. Menurut Singarimbun dan Effendi (2006:5) menerangkan bahwa yang dimaksud dengan penelitian explanatori adalah penelitian yang menjelaskan hubungan kausal antara variable -variabel melalui hipotesis.

Populasi dalam penelitian adalah pemeriksa pajak di kantor pelayanan pajak kendaraan bermotor. Jumlah sampel yang akan peneliti ambil adalah sebanyak 100 orang masyarakat atau wajib pajak kendaraan bermotor di kantor pelayanan pajak kendaraan bermotor Samsat Kota Yogyakarta.

Jenis data yang digunakan dalam penelitian ini adalah data primer. Data primer adalah data yang diperoleh atau dikumpulkan oleh orang yang melakukan penelitian atau yang bersangkutan yang memerlukannya. Data primer disebut juga data asli atau data baru (Nazaruddin dan Basuki, 2016). Selain itu, data primer merupakan data yang diperoleh melalui observasi, wawancara, serta kuisioner.

Sumber data penelitian ini adalah data primer berupa kuisioner yang dibagikan kepada responden atau wajib pajak yang melakukan pembayaran pajak yang tidak sengaja ditemui di kantorpelayanan pajak kendaraan bermotor Samsat Kota Yogyakarta serta juga dengan melakukan wawancara kepada respoden yang bersedia untuk diwawancara.

Penelitian ini terdiri dari satu variabel dependen yaitu kepatuhan wajib pajak dalam membayar PKB. Variabel dependen adalah variabel yang dipengaruhi atau menjadi akibat dari variabel independen, sedangkan variabel independen adalah variabel yang menjadi sebab timbulnya atau berubahnya variabel dependen (Sugiyono, 2007). Variabel independen dari penelitian ini terdiri dari tiga variabel yaitu kesadaran wajib pajak, pelayanan fiskus, serta sanksi perpajakan. Sedangkan variabel dependen dari penelitian ini adalah Kepatuhan Wajib Pajak dalam Membayar PKB. 
Teknik pengumpulan data yang digunakan dalam penelitian ini adalah dengan memberikan kuisioner dan juga melakukan wawancara. Kuisioner yaitu memberikan lembaran pertanyaan kepada responden untuk diisi sesuai dengan pertanyaan yang telah di ajukan secara tertulis sedangkan wawancara dengan memberi pertanyaan secara langsung kepada wajib pajak yang bersedia untuk diwawancarai.

\section{Uji Regresi Linier Berganda}

Analisis regresi ganda digunakan oleh peneliti apabila peneliti bermaksud meramalkan bagaimana keadaan (naik turunnya) variabel dependen (kriterium), bila dua atau lebih variabel independen sebagai faktor prediktor dimanipulasi (dinaik turunkan nilainya). Jadi, analisis regresi ganda akan dilakukan bila jumlah variabel independennya minimal 2 (Sugiyono, 2007). Persamaan regresi dari penelitian ini adalah: $\mathrm{KWP}=\alpha+\beta 1 \mathrm{X} 1+\beta 2 \mathrm{X} 2+\beta 3 \mathrm{X} 3+\mathrm{e}$

Keterangan

$\begin{array}{ll}\text { KWP } & \text { : Kepatuhan WP dalam membayar PKB } \\ \alpha & : \text { Konsanta } \beta 1, \beta 2, \beta 3, \beta 4 \\ \text { Koefisien Regresi X1 } & \text { Kesadaran Wajib Pajak } \\ \text { Koefisien Regresi X2 : } & \text { Kualitas Pelayanan Fiskus } \\ \text { Koefisien Regresi X3 : } & \text { Sanksi Perpajakan } \\ \text { e } & : \text { Eror atau variabel pengganggu }\end{array}$

\section{Uji t}

Menurut Imam Ghozali (2006) uji statistik t pada dasarnya menunjukkan seberapa jauh pengaruh satu variabel independen secara individual dalam menerangkan variabel dependen. Pengujian dilakukan dengan menggunakan signifikan level 0,05 ( $\alpha=5 \%)$. Penerimaan atau penolakan hipotesis dilakukan dengan kriteria:

1) Jika nilai signifikansi $\leq 0,05$ dan koefisien regresi bernilai positif maka hipotesis diterima (koefisien regresi signifikan). Ini berarti secara parsial variabel independen tersebut mempunyai pengaruh yang signifikan terhadap variabel dependen.

2) Jika nilai signifikansi $>0,05$ dan koefisien regresi bernilai negatif maka hipotesis ditolak (koefisien regresi tidak signifikan). Ini berarti secara parsial variabel independen tidak mempunyai pengaruh secara signifikan terhadap variabel dependen.

\section{Metoda Kualitatif}

Data Kualitatif adalah data yang berupa tulisan mengenai tingkah laku manusia yang dapat diamati. Data kualitatif itu berbentuk uraian terperinci, kutipan langsung dan dokumentasi kasus. Data ini dikumpulkan sebagai suatu cerita responden, tanpa mencoba mencocokkan suatu gejala dengan kategori baku yang telah ditetapkan 
sebelumnya, sebagaimana jawaban pertanyaan dalam kuesioner (Ariesto Hadi, 2010). Uji kualitatif menggunakan 5 item pertanyaan yaitu:Dari segi pelayanan yang diberikan apakah sudah baik?; Apakah menurut bapak pelayanan dapat meningkatkan kepatuhan wajib pajak?;Apakah yang menajdi dasar bapak dalam membayar pajak?;seberapa besar peran sanksi administrasi menurut bapak dalam menekan kepatuhan wajib pajak dalam membayar pajak?

\section{HASIL PENELITIAN}

\section{Analisis Kuantitatif}

Pengujian hipotesis dilakukan dengan menggunkana metode Regresi Linear Berganda yang bertujuan untuk menguji hubungan pengaruh antara satu variabel terhadap variabel lainnya. Analisis data menggunakan teknik statistik multiple regression untuk menguji pengaruh variabel-variabel independen terhadap variabel dependen, yaitu untuk mengetahui apakah terdapat pengaruh antara kesadaran wajib pajak, pelayanan fiskus dan sanksi administrasi terhadap kepatuhan wajib pajak. Analisis regresi linear berganda digunakan dalam penelitian ini dengan tujuan untuk mengetahui ada tidaknya pengaruh variabel bebas terhadap variabel terikat. Perhitungan statistik dalam analisis regresi linear berganda yang digunakan dalam penelitian ini adalah dengan menggunakan bantuan program komputer SPSS 16. Ringkasan hasil pengolahan data dengan menggunakan program SPSS tersebut adalah sebagai berikut:

Table 1 : Hasil Uji Regresi Linier Berganda

\begin{tabular}{|c|c|c|c|c|c|c|}
\hline & \multirow{2}{*}{ Model } & \multicolumn{2}{|c|}{$\begin{array}{l}\text { Unstandardized } \\
\text { Coefficients }\end{array}$} & \multirow{2}{*}{$\begin{array}{c}\begin{array}{c}\text { Standardized } \\
\text { Coefficients }\end{array} \\
\text { Beta }\end{array}$} & \multirow{2}{*}{$\mathbf{t}$} & \multirow{2}{*}{ Sig. } \\
\hline & & B & $\begin{array}{l}\text { Std. } \\
\text { Error }\end{array}$ & & & \\
\hline \multirow[t]{4}{*}{1} & (Constant) & 11.123 & 2.183 & & 5.096 & .000 \\
\hline & Kesadaran wajib pajak & .447 & .103 & .534 & 4.346 & .000 \\
\hline & Pelayanan fiskus & -.100 & .093 & -.122 & -1.072 & .286 \\
\hline & Sanksi administrasi & -.021 & .090 & -.024 & -.231 & .818 \\
\hline \multicolumn{4}{|c|}{ a. Dependent Variable: Kepatuhan wajib pajak } & & & \\
\hline
\end{tabular}

Persamaan regresi yang didapat dari hasil prhitungan adalah sebagai berikut :

Kepatuhan Wajib Pajak $=11,123+(0,447$ Kesadaran wajib Pajak $)+(-0,100$ Pelayanan Fiskus $)+(-0,021$ Sanksi Administrasi) 
Berdasarkan regresi diatas, dapat diinterpretasikan sebagai berikut:

1. Nilai konstanta 11,123 menunjukkan besarnya kepatuhan wajib pajak adalah 11,123 jika variabel kesadaran wajib pajak (X1), pelayanan fiskus (X2), sanksi administrasi (X3) adalah 0 (nol).

2. Berdasarkan persamaan regresi menunjukkan bahwa variabel kesadaran wajib pajak (X1), mempunyai arah koefisien regresi positif dengan kepatuhan wajb pajak yaitu $\mathrm{b}=0,447$ yang berarti bahwa apabila produk mengalami peningkatan $1 \%$ maka kepatuhan wajib pajak akan meningkat 44,7\% dengan asumsi variabel independen yang lain konstan.

3. Berdasarkan persamaan regresi menunjukkan bahwa variabel pelayanan fiskus (X2) mempunyai arah koefisien regresi negatif dengan kepatuhan wajib pajak yaitu $b=-0,100$ yang berarti bahwa apabila harga mengalami peningkatan $1 \%$ maka kepatuhan wajib pajak akan menurun sebesar 10,0\% dengan asumsi variabel independen yang lain konstan.

4. Berdasarkan persamaan regresi menunjukkan bahwa variabel sanksi administrasi (X3) mempunyai arah koefisien regresi negatif dengan kepatuhan wajib pajak yaitu $b=-0,021$ yang berarti bahwa apabila pelayanan fiskus mengalami peningkatan $1 \%$ maka kepatuhan wajib pajak akan menurun sebesar $2,1 \%$ dengan asumsi variabel independen yang lain konstan.

\section{Pembahasan Analisis Kuantitatif}

\section{Kesadaran wajib pajak berpengaruh positif terhadap kepatuhan wajib pajak}

Berdasarkan hasil pengujian hipotesis secara parsial (Uji t) diketahui variabel Kesadaran wajib pajak memiliki nilai signifikan sebesar 0,000 yang berarti lebih kecil dari 0,05 dengan nilai t sebesar 4,346. Hasil tersebut menunjukkan bahwa variabel kesadaran wajib pajak berpengaruh positif terhadap kepatuhan wajib pajak, sehingga hipotesis pertama yang diajukan diterima.. Hasil ini juga mendukung penelitian Irianingsih (2015) yang menunjukkan bahwa kesadaran wajib pajak berpengaruh positif terhadap kepatuhan wajib pajak.

Kesadaran Wajib Pajak dapat meningkatkan Kepatuhan Wajib Pajak dalam membayar pajak kendaraan bermotor. Adanya Kesadaran Wajib Pajak makaWajib Pajak akan selalu membayar pajak tepat waktu. Hal ini menunjukkan bahwa kesadaran Wajib Pajak sangat diperlukan untuk mendorong Wajib Pajak memenuhi kewajibannya. Kesadaran membayar pajak dapat memunculkan sikap patuh, taat dan disiplin. Kesadaran membayar pajak muncul dari diri Wajib Pajak dengan semakin menikmati sarana dan prasarana publik yang semakin baik. Wajib pajak harus menyadari dan mempertimbangkan bahwa pajak merupakan suatu bentuk partisipasi dalam menunjang pembangunan negara. Dengan menyadari hal ini, wajib pajak mau membayar pajak karena merasa tidak dirugikan dari pemungutan pajak yang dilakukan. 


\section{Pelayanan fiskus berpengaruh positif terhadap Kepatuhan Wajib Pajak Dengan}

Berdasarkan hasil pengujian hipotesis secara parsial (Uji t) diketahui variabel pelayanan fiskus memiliki nilai signifikan sebesar 0,286 yang berarti lebih besar dari 0,05 dengan nilai t sebesar -1,072. Hasil tersebut menunjukkan bahwa variabel pelayanan fiskus berpengaruh negatif terhadap kepatuhan wajib pajak, sehingga hipotesis kedua yang diajukan ditolak. Hasil ini tidak mendukung penelitian Mustika (2012) yang menunjukkan bahwa pelayanan fiskus berpengaruh positif terhadap kepatuhan wajib pajak.

Pelayanan Fiskus tidak dapat meningkatkan Kepatuhan Wajib Pajak dalam membayar pajak kendaraan bermotor. Semakin baik Pelayanan Fiskus maka Kepatuhan Wajib Pajak dalam membayar pajak akan semakin berkurang. Hal ini menunjukkan bahwa semakin Wajib Pajak mendapat kan Pelayanan Fiskus yang baik maka Kepatuhan Wajib Pajak dalam membayar pajak akan berkurang, sehingga Pelayanan Fiskus tidak berpengaruh terhadap Kepatuhan Wajib Pajak.

\section{Sanksi Administrasi Pajak berpengaruh positif terhadap Kepatuhan Wajib Pajak}

Berdasarkan hasil pengujian hipotesis secara parsial (Uji t) diketahui variabel sanksi administrasi memiliki nilai signifikan sebesar 0,818 yang berarti lebih besar dari 0,05 dengan nilai t sebesar -0,231. Hasil tersebut menunjukkan bahwa variabel sanksi administrasi berpengaruh negatif terhadap Kepatuhan wajib pajak, sehingga hipotesis ketiga yang diajukan ditolak. Hasil ini tidak mendukung penelitian Wardani dan rumiyatun (2017) yang menunjukkan bahwa pelayanan fiskus berpengaruh positif terhadap kepatuhan wajib pajak.

Kesadaran perpajakan adalah keadaan mengetahui atau mengerti perihal pajak tanpa adanya paksaan dari pihak lain. Penilaian positif masyarakat wajib pajak terhadap pelaksanaan fungsi negara oleh pemerintah akan menggerakan masyarakat untuk mematuhi kewajibannya untuk membayar pajak (Ummah, 2015). Untuk lebih meningkatkan kepatuhan wajib pajak kendaraan bermotor, sanksi pajak kendaraan bermotor juga diperlukan guna untuk penegakan hukum dalam diwujudkan ketertiban wajib pajak dalam membayar pajaknya. Sanksi pajak memiliki peran penting guna memberikan pelajaran bagi pelanggar pajak agar tidak meremehkan peraturan perpajakan (Sari dan Susanti, 2013).

Sanksi Administrasi Pajak yang ditetapkan tidak meningkatkan adanya Kepatuhan Wajib Pajak dalam membayar pajak kendaraan bermotor. Semakin Wajib Pajak mengetahui tentang Sanksi Administrasi Pajak maka Kepatuhan Wajib Pajak dalam membayar pajak akan semakin berkurang. Sehingga Sanksi Administrasi Pajak tidak berpengaruh terhadap Kepatuhan Wajib Pajak.

\section{Analisis Kualitatif}

Wawancara dilakukan kepada 20 wajib pajak yang sedang membayar pajak di kantor pelayanan pajak kendaraan bermotor kota Yogyakarta. Dalam wawancara berikut 
peneliti mengelompokkan jawaban responden yang memiliki inti jawaban yang sama dan condong saling mendukung.

\section{Pembahasan Analisis Kualitatif}

\section{Kesadaran wajib pajak berpengaruh terhadap kepatuhan wajib pajak}

Berdasarkan hasil wawancara yang telah dilakukan pada beberapa responden menunjukkan bahwa faktor Kesadaran wajib pajak berpengaruh terhadap kepatuhan wajib pajak. Banyak responden yang membayar pajak karena mereka sadar bahwa fasilitas negara dapat berkembang salah satunya adalah karena adanya pemasukan dan pemasukan terbesar disumbangkan oleh sektor pajak. Tapi juga tidak sedikit mengatakan bahwa kesadaran tumbuh karena takut akan aturan berupa sanksi.Hasil analisis konten dari transkrip wawancara yang dilakukan tersebut menunjukkan bahwa kondisi ini sesuai dengan hasil yang diperoleh dari pendekatan kuantitatif. Bahwa kesadaran wajib pajak berpengauh positif terhadap kepatuhan wajib pajak dalam membayar PKB.

\section{Pengaruh pelayanan fiskus tidak berpengaruh terhadap Kepatuhan Wajib Pajak Dengan}

Berdasarkan hasil wawancara yang telah dilakukan pada beberapa responden menunjukkan bahwa faktor pelayanan fiskus tidak terlalu berpengaruh secara terhadap kepatuhan wajib pajak. Banyak responden yang membayar pajak tidak tau pelayanan yang sebenarnya bagus itu seperti apa, jika dari kenyamanan, fasilitas dan kebersihan saja mereka merasa itu kurang cukup untuk menarik wajib pajak dalam membayar pajak dan jika pelayanan yang dimaksud adalah para petugas banyak yang merasa fasilitas saja kurang cukup untuk menarik wajib pajak dalam membayar pajak karena wajib pajak yang tidak pernah atu belum pernah membayar pajak tidak akan tau pelayanan seperti apa yang akan mereka terima sehingga banyak wajib pajak yang memilih untuk menyuruh orang lain untuk membayarkan pajaknya.Hasil analisis konten dari transkrip wawancara yang dilakukan tersebut menunjukkan bahwa kondisi ini sesuai dengan hasil yang diperoleh dari pendekatan kuantitatif. Bahwa pelayanan fiskus berpengaruh negatif terhadap kepatuhan wajib pajak dalam menbayar PKB.

\section{Pengaruh Sanksi Administrasi Pajak tidak berpengaruh terhadap Kepatuhan Wajib Pajak}

Berdasarkan hasil wawancara yang telah dilakukan pada beberapa responden menunjukkan bahwa faktor Sanksi Administrasi kurang begitu berpengaruh terhadap kepatuhan wajib pajak. Banyak responden yang mengatakan jika walaupun sanksi ada tapi kesadaran wajib pajaknya tidak ada juga akan sia-sia.Hasil analisis konten dari transkrip wawancara yang dilakukan tersebut menunjukkan bahwa kondisi ini sesuai dengan hasil yang diperoleh dari pendekatan kuantitatif. Bahwa ssanksi administrasi berpengaruh negatif terhadap kepatuhan wajib pajak dalam membayar PKB. 


\section{KESIMPULAN DAN SARAN}

Berdasarkan analisis data dan pembahasan yang telah dilakukan maka dapat disimpulkan bahwa:

1. Hasil pengujian hipotesis secara parsial (Uji t) diketahui variabel Kesadaran wajib pajak memiliki nilai signifikan sebesar 0,000 yang berarti lebih kecil dari 0,05 dengan nilai t sebesar 4,346. Hasil tersebut menunjukkan bahwa variabel kesadaran wajib pajak berpengaruh positif terhadap kepatuhan wajib pajak, sehingga hipotesis pertama yang diajukan diterima. Hasil ini juga mendukung penelitian Irianingsih (2015) yang menunjukkan bahwa kesadaran wajib pajak berpengaruh positif terhadap kepatuhan wajib pajak.

2. Hasil pengujian hipotesis secara parsial (Uji t) diketahui variabel pelayanan fiskus memiliki nilai signifikan sebesar 0,286 yang berarti lebih besar dari 0,05 dengan nilai t sebesar -1,072. Hasil tersebut menunjukkan bahwa variabel pelayanan fiskus berpengaruh negatif terhadap kepatuhan wajib pajak, sehingga hipotesis kedua yang diajukan ditolak. Hasil ini tidak mendukung penelitian Mustika (2012) yang menunjukkan bahwa pelayanan fiskus berpengaruh positif terhadap kepatuhan wajib pajak.

3. Hasil pengujian hipotesis secara parsial (Uji t) diketahui variabel sanksi administrasi memiliki nilai signifikan sebesar 0,818 yang berarti lebih besar dari 0,05 dengan nilai t sebesar -0,231. Hasil tersebut menunjukkan bahwa variabel sanksi administrasi berpengaruh negatif terhadap Kepatuhan wajib pajak, sehingga hipotesis ketiga yang diajukan ditolak. Hasil ini tidak mendukung penelitian Wardani dan rumiyatun (2017) yang menunjukkan bahwa pelayanan fiskus berpengaruh positif terhadap kepatuhan wajib pajak.

Data diatas merupakan kesimpulan dari penelitian kuantitatif yang peneliti lakukan dan hasil penelitian kualitatif yang peneliti lakukan mendukung hasil penelitian kuantitaif yang peneliti lakukan. Dengan hasil : kesadaran berpengaruh positif terhadap kepatuhan wajib pajak, pelayanan fiskus berpengaruh negatif terhadap kepatuhan wajib pajak dan juga sanksi fiskus berpengaruh negatif terhadap kepatuhan wajib pajak.

Saran untuk penelitian selanjutnya adalah:

1. Untuk SAMSAT kota Yogyakarta, karena berdasarkan penelitan ini factor yang paling mempengaruhi wajib pajak untuk patuh adalah kesadaran maka, diharapkan agar pihak terkait melakukan sosialisasi kepada waji pajak yang dimana sosialisasi yang dilakukan dapat menumbuhkan kesadaran wajib pajak dalam membayar pajak kendaraan bermotor.

2. Peneliti selanjutnya hendaknya menambahkan variabel bebas diluar yang telah peneliti tulis, seperti Program Sensus pajak Nasional, sosialisasi pajak dan tingkat pendidikan sehingga disarankan dapat memberikan hasil penelitian yang lebih baik, lengkap, dan bermanfaat.

3. Peneliti selanjutnya juga diharapkan dapat menarik responden agar mau dan tertarik untuk diwawancara. 
4. Penelitian selanjutnya diharapkan dapat tetap menggunakan metoda campuran (kuantitatif dan kualitatif) karena metoda ini mempunyai hasil pemahaman yang lebih luas.

\section{DAFTAR PUSTAKA}

Alviansyah, Tri Palira. 2011. "Pengaruh Sanksi, Pelayanan, Tingkat Pengetahuan Wajib Pajak Terhadap Tingkat Kepatuhan Penyampaian SPT Masa Wajib Pajak Orang Pribadi (Studi Kasus KPP Malang Utara)".

Halim, Abdul. 2004. "Management Keuangan Daerah", Yogyakarta : UPP AMP

Halim, Abdul., Icuk ,Rangga B., Amin, Dara. 2014. "Perpajakan: Konsep, Aplikasi, Contoh, dan Studi Kasus”. Jakarta : Penerbit Salemba.

Ihsan, Muchsin. 2013. "Pengaruh Pengetahuan Wajib Pajak, Penyuluhan Pajak, Kualitas Pelayanan Pajak, Dan Pemeriksaan Pajak Terhadap Kepatuhan Wajib Pajak Badan Di Kota Padang. Fakultas Ekonomi Universitas Negeri Padang".

Indrawati \& Setiawan W. 2009. PembelajaranAktif, Kreatif, dan Menyenangkan pdf, e-book. Jakarta: Pusat Pengembangan dan Pemberdayaan Pendidik dan Tenaga Kependidikan Ilmu Pengetahuan Alam (PPPPTKIPA).

Irianingsih, Eka. 2015. "Pengaruh Kesadaran Wajib Pajak, Pelayanan Fiskus dan Sanksi Administrasi Pajak Terhadap Kepatuhan Wajib Pajak Dalam Membayar Pajak Kendaraan Bermotor (PKB) Kantor Pelayanan Pajak Kendaraan Bermotor SAMSAT Sleman".

Istanto, Fery.2010.“Analisis Pengaruh Pengetahuan Tentang Pajak, Kualitas Pelayanan Pajak, Ketegasan Sanksi Perpajakan, dan Tingkat Pendidikan Terhadap Motivasi Wajib Pajak dalam Membayar Pajak.Skripsi Strata1. Jakarta:Fakultas Ekonomi dan Bisnis UIN Syarif Hidayatullah”.

Isyatir, Anis Isnaini Nur. 2015. "Pengaruh Kualitas Pelayanan Fiskus dan Sanksi Pajak Terhadap Kepatuhan Membayar Pajak Kendaraan Bermotor Di Kabupaten Karanganyar Tahun 2014. Universitas Muhammadiyah Surakarta".

Jatmiko, Agus Nugroho. 2006. "Pengaruh sikap wajib pajak pada pelaksanaan sanksi denda, pelayanan fiskus, dan kesadaran perpajakan terhadap kepatuhan wajib pajak”. Tesis. Semarang: Program Studi Magister Akuntansi Pasca Sarjanan Universitas Diponegoro.

Muliarni dan Setiawan. 2009. "Pengaruh Persepsi tentang sanksi perpajakan dan kesadaran wajib pajak pada kepatuhan pelaporan wajib pajak orang pribadi di kantor pelayanan pajak prata Denpasar Timur" 
Nasution, Chairuddin Syah. 2003. “Analisis Potensi Dan Pertumbuhan Penerimaan Pajak Penghasilan (PPh) Di Indonesia Periode 1990 - 2000”. Kajian Ekonomi Dan Keuangan, Vol. 7, No. 2.

Nazir. M 2005. “Metodologi penelitian”. Bogor : Ghalia Indonesia.

Nurlaela, Siti. 2013. "Pengaruh Pengetahuan dan Pemahaman, Kesadaran, Persepsi terhadap Kemauan Membayar Pajak Wajib PajakOrang Pribadi yang Melakukan Pekerjaan Bebas”.

Nurmuntu, Safri. 2005. “Pengantar Perpajakan”. Jakarta: Granit

Mardiasmo,2011,Perpajakan,Edisi Revisi,Andi: Yogyakarta.

Muliari dan Setiawan. 2009. "Pengaruh Persepsi tentang Sanksi perpajakan dan Kesadaran Wajib Pajak pada Kepatuhan Pelaporan Wajib Pajak Orang Pribadi di Kantor Pelayanan Pajak Prata Denpasar Timur”.

Priyatno, Dwi. 2014. "SPSS 22 Pengolah Data Terpraktis”, Yogyakarta : Penerbit Andi.

Rahayu, Siti. 2010. “Perpajakan Indonesia: Konsep \& Aspek Formal'Yogyakarta: Graha Ilmu

Setiawan. Agus 2006. "Rekonsiliasi dan Akuntansi PPh Badani, Penerbit T \& A Software Development”, Jakarta.

Siahaan, Marihot Pahala. 2013. “Edisi Revisi Pajak Daerah \& Retribusi Daerah”. Jakarta: RajaGrafindo Persada.

Singarimbun, Masri dan Efendi Sofian. 2006. "Metode Penelitian Survai” . Jakarta: LP3ES.

Sugiyono, 2004, “Statistika untuk Penelitian”, Cetakan Keenam, Penerbit Alfabeta, Bandung.

Supriyati, dan Nur Hidayati. 2008. "Pengaruh Pengetahuan Wajib Pajak dan Persepsi Wajib Pajak”. Jurnal Akuntansi \& Teknologi Informasi, Vol.7 No.1, Mei 2008.

Susanto, Herry., 2012. “Juara II Lomba Artikel Pajak Nasional Direktorat Jenderal Pajak”. Melalui www.pajak.go.id. Diakses 2 Juli 2014, 22:00 WIB

Zuraida, Ida. 2012, “Teknik Penyusunan Peraturan Daerah tentang Pajak Daerah dan Retribusi Daerah”. Jakarta: Sinar Grafika. 